\title{
Apoptosis-inducing effects of jujube (Zăo) seed extracts on human Jurkat leukemia T cells
}

\author{
Natthanan Taechakulwanijya ${ }^{1}$, Natthida Weerapreeyakul ${ }^{2}$, Sahapat Barusrux ${ }^{3}$ and Sirithorn Siriamornpun ${ }^{4}$
}

\begin{abstract}
Background: Jujube (Zão) seeds exhibited anticancer effects and used in Chinese medicine for many years. This study aims to investigate the apoptosis-inducing effects of seed extracts from eight different cultivated species ('Apple,',Bombay,',Jumbo', 'Kaew,',Nomsod,' 'Rianthong','Samros', and 'Taiwan') on human Jurkat leukemia T cells.

Methods: We evaluated the effects of seed extracts from eight jujube cultivated species on human Jurkat leukemia T cells. The crude seed extracts were prepared sequentially by using water, $95 \%$ ethanol, dichloromethane, ethyl acetate, chloroform or hexane. The antiproliferative effects of the jujube seed extracts relative to that of melphalan were evaluated by neutral red assays. Apoptotic cell death induced by the ethanolic extracts at $1 \times I C_{50}$ and $2 \times I C_{50}$ concentrations was demonstrated by DAPI staining, gel electrophoresis, flow cytometry with Annexin V/propidium iodide staining, and caspase-3, -8, and -9 enzyme activities.

Results: Ethanolic extracts of 'Taiwan,',Jumbo,',Nomsod,',Rianthong,',Samros', and 'Bombay', significantly inhibited the proliferation of Jurkat cells compared with untreated cells (all $P<0.001$ ), while the extracts of 'Kaew' and 'Apple' were inactive. The six active extracts preferentially induced apoptotic cell death in a concentration-dependent manner with DNA fragmentation $\left(2 \times I C_{50}\right)$. Increased caspase-3 activity was detected after treatment with the six extracts. The'Taiwan','Nomsod','Jumbo', and 'Rianthong' extracts $\left(2 \times I_{50}\right)$ induced both the extrinsic and intrinsic apoptosis pathways by increasing caspase- 8 and caspase-9 activity, respectively. Alkaloids (Dragendorff's method) and reducing sugars (Fehling's test) were mainly identified in the apoptosis-inducing extracts.
\end{abstract}

Conclusions: The tested of six active extracts ('Taiwan,',Jumbo,',Nomsod,' 'Rianthong,' 'Samros' and 'Bombay') contained alkaloids or reducing sugars, and induced caspase-dependent apoptosis in human Jurkat leukemia T cells.

Keywords: Jujube, Apoptosis, Jurkat leukemia T cells, Cancer

\section{Background}

Complementary and alternative medicines have been evaluated in addition to chemotherapy, radiation, and surgery in treating cancer. The development of an effective strategy for cancer drug discovery has been outlined [1]. Apoptosis is a major target for chemoprevention and chemotherapy [2].

Jujube $(Z a \check{o} o)$ is a functional food with nutritional value that is consumed in Asia, the Mediterranean and

\footnotetext{
*Correspondence: natthida@kku.ac.th

${ }^{2}$ Faculty of Pharmaceutical Sciences, Khon Kaen University, Khon

Kaen 40002, Thailand

Full list of author information is available at the end of the article
}

the United States [3-6]. The two extant species include Indian jujube (Ziziphus mauritiana Lam.) and Chinese jujube (Ziziphus jujuba Mill.) [4], and were reported to exhibit sedative, anodyne, pectoral, stomachic, styptic, and tonic effects [7], as well as anticancer, antianxiolytic, antifungal, and antispastic effects [8].

Different parts of $Z$. mauritiana and $Z$. jujuba exhibit various medicinal effects. $Z$. jujuba has long been used as a crude drug in Chinese medicine [5]. The seeds of $Z$. jujuba enhanced cell membrane permeability for drugs [9] and exhibited sedative effects [10]. Linoleic and stearic acids from seed extracts of $Z$. jujuba significantly inhibited cyclooxygenase (COX)-1 and COX-2 activity 
[11]. The fruits of $Z$. jujuba activated choline acetyltransferase and increased acetylcholine synthesis [12], through both antioxidant $[13,14]$ and anti-allergenic [15] effects. Triterpenoids from the leaves of $Z$. jujuba were sweetness inhibitors [16]. The leaves of $Z$. mauritiana protected the liver from alcohol damage [17]. The bark of $Z$. mauritiana possessed both antiulcer [18] and antifertility [19] activities. The roots of $Z$. mauritiana exhibited antifungal [20] and antidiarrheal [21] activities. The functional constituents of jujube possessed anticancer activity [22]. Z. jujuba fruits induced apoptosis in liver (HepG2) and breast (MCF-7 and KBR3) cancer cell lines [7, 23]. The seeds of $Z$. mauritiana induced apoptosis in promyelocytic leukemia cells (HL-60) [24].

New jujube hybrids are crossbred from the two varieties (Z. jujuba and Z. mauritiana). Presently, many new cultivated varieties are available in Thailand and independently exhibit various biological functions [25-27]. Evidence of changes in phytoconstituents between the wild-type plants and new cultivars has been reported $[28,29]$. The metabolites found in the leaves of new carrot cultivars possessed higher contents of feruloyl acid, quinic acid, malic acid, and leucine, but lower contents of glucose and sucrose than the wild-type ( $Z$. mauritiana) [28]. A new peanut cultivar possessed higher $4 \alpha$-monomethylsterol contents, but lower 4-desmethylsterol and triterpene alcohol contents than the wild-type plant [29].

This study aims to investigate the apoptosis-inducing effects of seed extracts from eight different jujube cultivated species ('Apple, 'Bombay,' 'Jumbo', 'Kaew,' 'Nomsod', 'Rianthong,, 'Samros', and 'Taiwan') on human Jurkat leukemia $\mathrm{T}$ cells. The anticancer activities were evaluated based on the cytotoxicity and apoptosis-inducing effects on human Jurkat leukemia $\mathrm{T}$ cells, relative to melphalan as a positive control. Nuclear morphological changes and caspase-mediated apoptosis were determined. Phytochemical groups in the seed extracts were identified.

\section{Methods}

\section{Chemicals and reagents}

Methanol, isopropanol, dichloromethane, ethyl acetate, chloroform, and hexane were purchased from RCI Labscan Ltd., Thailand, and $95 \%$ ethanol from J.T. Baker ${ }^{\circledR}$ (Center Valley, PA, USA). Sodium hydroxide, citric acid and hydrochloric acid were obtained from BDH Prolabo chemicals (Poole, UK) Neutral red and 4-(p-nitrobenzyl) pyridine (NBP) and acetonitrile were obtained from Sigma-Aldrich ${ }^{\circledR}$ (St. Louis, MO, USA). Melphalan, 4,6-diamidino-2-phenylindole (DAPI), copper (II) sulfate were from Sigma-Aldrich Chemie $\mathrm{GmbH}$ (Munich, Germany). Dulbecco's modified Eagle medium (DMEM),
RPMI Media 1640, fetal bovine serum and penicillin streptomycin were from GIBCO, Invitrogen Corp. (Grand Island, NY, USA). Sodium chloride and boric acid were from Vivantis Inc., (Oceanside, CA, USA). Dimethylsullfoxide (DMSO) (molecular grade) was from Sigma-Aldrich Chemie GmbH (Saint-Quentin Fallavier, France). Trypan blue was from Fluka Chemika (Buchs, Switzerland) and potassium sodium tartrate was from Loba Chemie (Mumbai, India). Agarose molecular grade was purchased from Bio-Rad (Hercules, CA, USA). A 100 bp DNA ladder marker was purchased from Invitrogen (Carlsbad, CA, USA). Caspase-Glo ${ }^{\circledR} 3 / 7,8$ and 9 were purchased from Promega (Madison, WI, USA).

\section{Preparation of crude extracts}

Eight jujube cultivated species ('Apple,' 'Bombay,' 'Jumbo', 'Kaew', 'Nomsod, 'Rianthong,' 'Samros' and 'Taiwan') were commercially cultivated and authenticated based on fruit and seed morphological characters by Assistant Professor Thaweesak Thitimetharoch, Division of Pharmacognosy and Toxicology, Faculty of Pharmaceutical Sciences, Khon Kaen University. The jujubes were collected from the local market in Amphoe Muang, Khon Kaen, Thailand, in 2012. The picture vouchers of the specimens (NW-55-2012-NW-62-2012) were deposited at the herbarium of the Faculty of Pharmaceutical Sciences, Khon Kaen University, Khon Kaen province, Thailand. The seed characteristics of each jujube cultivated species (five samples for each) are presented in Fig. 1. The seed was separated and dried at $\leq 55{ }^{\circ} \mathrm{C}$. The seeds were macerated in deionized water $(1 \mathrm{~g}: 3 \mathrm{~mL})$ overnight. The water crude extract was collected after being freeze-dried. The remaining residue from water extraction was dried at $55{ }^{\circ} \mathrm{C}$ and further macerated with $95 \%$ ethanol, dichloromethane, ethyl acetate, chloroform or hexane, respectively. Each round of solvent extraction lasted $72 \mathrm{~h}$, using different dry residue to solvent ratios $(1 \mathrm{~g}: 3 \mathrm{~mL})$. Solvent was removed by a rotary evaporator (IKA ${ }^{\circledR}$, Staufen, Germany), resulting in a dry residue. Six types of crude extract were obtained for each cultivars. The crude extracts were stored at $-20^{\circ} \mathrm{C}$. The concentrations of 10 , $25,50,100,250$ and $500 \mu \mathrm{g} / \mathrm{mL}$ were used in the antiproliferation study.

\section{Cell culture}

The human Jurkat leukemia $\mathrm{T}$ cells were cultured in RPMI 1640 media while the normal African green monkey kidney epithelial cell line (Vero) was cultured in DMEM. Both cell lines were provided by Associate Professor Sahapat Barusrux. Both media were maintained with $10 \%$ fetal bovine serum and $1 \%$ penicillin-streptomycin. Cells were incubated at $37^{\circ} \mathrm{C}$ and $5 \% \mathrm{CO}_{2}$. 


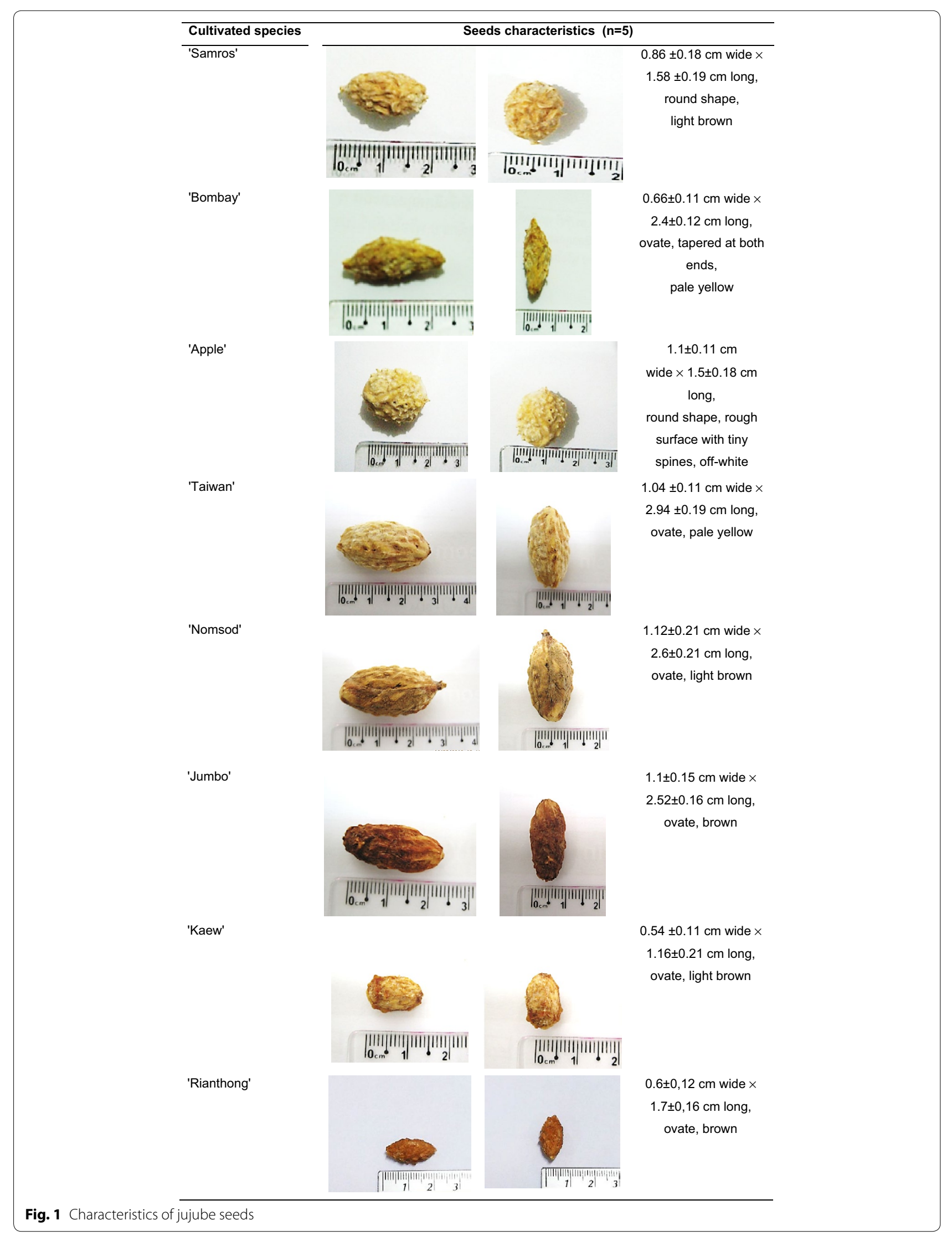




\section{Antiproliferation assay}

The antiproliferation test was determined based on modified neutral red assay [30]. A Jurkat cell density of $5 \times 10^{5}$ cells $/ \mathrm{mL}$ and Vero $3 \times 10^{5}$ cells $/ \mathrm{mL}$ were seeded in 96-well plates and maintained at $37{ }^{\circ} \mathrm{C}$ for $24 \mathrm{~h}$ in humidified $5 \% \mathrm{CO}_{2}$. The extracts dissolved in DMSO were pipetted into each well to generate various final concentrations ranging between 10 and $500 \mu \mathrm{g} / \mathrm{mL}$. The final concentration of DMSO did not exceed $1 \% \mathrm{v} / \mathrm{v}$ to minimize the cytotoxic effect of DMSO [30]. After treatment with the extracts for $24 \mathrm{~h}$, cells were re-suspended. Neutral red dyes $(50 \mu \mathrm{g} / \mathrm{mL})$ were added to each well. Cells were incubated for another $2 \mathrm{~h}$, then washed with $1 \times \mathrm{PBS}(\mathrm{pH} 7.4)$ and lysed with $0.33 \% \mathrm{HCl}$ in isopropanol. The absorbance of viable cells and dye solution was measured at $537 \mathrm{~nm}$ (650 nm reference wavelength) by a microplate reader (TECAN, Grödig, Austria). The untreated cells comprised the control group and cells treated with alkylating drug melphalan are the positive control. A plot of \%cell viability and various extract concentrations was used to calculate the $\mathrm{IC}_{50}$-which represents the concentration possessing $50 \%$ antiproliferation. The selectivity index (SI) was calculated from the $\mathrm{IC}_{50}$ of the extracts in normal Vero cells over the Jurkat cancer cells to indicate the cytotoxic selectivity (i.e., safety) of the crude extracts [31].

\section{Detection of apoptosis \\ Nuclear morphological alteration}

Morphological changes in cell nuclei undergoing apoptosis was determined by DAPI staining [32]. The stained nuclei were then detected by a fluorescent microscope (Nikon Eclipse 80i, Kanagawa, Japan). Cells were seeded in 24-well plates at a density of $3 \times 10^{5}$ cells $/ \mathrm{mL}$ per well and incubated for $24 \mathrm{~h}$. Cells were treated with $500 \mu \mathrm{g} /$ $\mathrm{mL}$ extracts and incubated for another $24 \mathrm{~h}$. Then cells were washed with PBS and collected by centrifugation (Daihan Scientific, Seoul, Korea) at $1677 \mathrm{~g}$ for $5 \mathrm{~min}$. Cells were fixed in ice-cold methanol for $15 \mathrm{~min}$. After the methanol was removed, the cells were incubated for $30 \mathrm{~min}$, at room temperature, in the dark, with $0.3 \mu \mathrm{g} /$ $\mathrm{mL}$ DAPI. The mixture of PBS to glycerin (at a 1:1 ratio) was added to achieve a $20-\mu \mathrm{L}$ volume. Cells were wetmounted on a glass slide and observed under a fluorescent microscope by fluorescence filters with an excitation band of $358 \mathrm{~nm}$ and an emission of $461 \mathrm{~nm}$. The images of stained nuclei were captured by the NIS-Element AR 3.2 imaging software (Nikon Instruments Inc, NY, USA).

\section{Mode of cell death}

Flow cytometry was used to determine various types of cell death including early and late stage apoptosis as well as necrosis. Annexin V-FITC and propidium iodide
(Annexin V-FITC apoptosis detection kit, eBiosciences, Inc., San Diego, CA, USA) [33]. Cells were seeded in 24-well plates at a density of $5 \times 10^{5}$ cells $/ \mathrm{ml}$ per well and incubated for $24 \mathrm{~h}$. Cells were treated with the crude extracts at a concentration of $1 \times \mathrm{IC}_{50}$ and $2 \times \mathrm{IC}_{50}$, obtained from the antiproliferation study at 12 and $24 \mathrm{~h}$. Afterward, cells were harvested by centrifugation (Wisds' Laboratory Instruments, Korea) at $1677 g$ for $5 \mathrm{~min}$ then the supernatant was removed. The cells were washed with $200 \mu \mathrm{L}$ of $1 \mathrm{x}$ binding buffer. After removal of the supernatant, $95 \mu \mathrm{L}$ of binding buffer and $5 \mu \mathrm{L}$ Annexin V-FITC were added and the mixture incubated in the dark for $15 \mathrm{~min}$ at room temperature. Then $95 \mu \mathrm{L}$ of binding buffer and $5 \mu \mathrm{L}$ of propidium iodide (final concentration of $2 \mu \mathrm{g} / \mathrm{mL}$ per cell sample) were pipetted into an Eppendrof tube and the mixture incubated for $15 \mathrm{~min}$ in the dark at the room temperature. Cells were re-suspended in $200 \mu \mathrm{L}$ of binding buffer. The stained cells were analyzed immediately by flow cytometry (BD FACSCanto II, Franklin Lakes, NJ, USA) by FACSDiva software version 6.1.3 (BD Biosciences, San Jose, CA, USA).

\section{Caspases activity}

The activity of caspase- $3 / 7,-8$ and -9 were evaluated to confirm whether apoptosis was induced by the jujube seed extract(s) and to determine the apoptosis induction pathway. Jurkat cells $\left(1.3 \times 10^{4}\right.$ cells/well $)$ were seeded into 96-well white plates (Costar ${ }^{\mathrm{TM}}$, Corning, NY, USA). Cells were incubated at $37^{\circ} \mathrm{C}$ for $24 \mathrm{~h}$ and extracts added to each well for a final concentration of $2 \times \mathrm{IC}_{50}$. Treated cells were incubated at various intervals. Supernatant $(50 \mathrm{~mL})$ was pipetted out of each well and $50 \mu \mathrm{L}$ of caspase reagent mixture added and incubated in the dark for $40 \mathrm{~min}$ [34]. The relative luminescence units (RLU) were measured at $562 \mathrm{~nm}$ by a Multifunction Microplate Reader (Varioskan ${ }^{\text {TM }}$ Flash Multimode Reader, Thermo Scientific, USA) equipped with SkanIt Software 2.4.3 DDE's program (Thermo Scientific, Waltham, MA USA).

\section{DNA fragmentation}

Late stage apoptotic death mode was confirmed by a DNA fragment assay. Cells $\left(2 \times 10^{6}\right.$ cells $/ \mathrm{mL}$ density) were seeded in 24-well plates and incubated for $24 \mathrm{~h}$. Cells were treated with the jujube seed extracts as described above in the cell death mode assay. Cells were harvested and washed with PBS. After PBS was removed, $300 \mu \mathrm{L}$ of lysis buffer (FlexiGenen DNA kit; Qiagen, Germany) was added to each well and mixed thoroughly. After that $150 \mu \mathrm{L}$ of denaturation buffer and $20 \mu \mathrm{L}$ of Protease $\mathrm{K}(10 \mathrm{mg} / \mathrm{mL})$ were added to the reaction mixture. Cells were incubated at $65{ }^{\circ} \mathrm{C}$ for $15 \mathrm{~min}$ and $600 \mu \mathrm{L}$ of absolute isopropanol added and thoroughly mixed until the DNA became visible. DNA was collected 
after centrifugation (Daihan Scientific, Seoul, Korea) at $10,000 \mathrm{~g}$ for $5 \mathrm{~min}$. The supernatant was discarded and the pellet washed with $70 \%$ ethanol. After the liquid was removed by inverting the Eppendrof tube onto a clean piece of paper, $15 \mu \mathrm{L}$ of hydration buffer was added to dissolve the DNA for $15 \mathrm{~min}$ at $65{ }^{\circ} \mathrm{C}$. The resulting $300 \mathrm{ng} / \mu \mathrm{L}$ of DNA (DNA counting by GE healthcare Life Sciences, United Kingdom) was analyzed by electrophoresis on $1.8 \%$ agarose gels containing $0.75 \%$ ethidium bromide. The DNA was mixed with $6 \times$ loading dye and the gel was electrophoresed in $0.5 \mathrm{xTBE}$ buffer at $90 \mathrm{~V}$ for $1 \mathrm{~min}$ and $50 \mathrm{~V}$ for $1 \mathrm{~h}$. DNA fragmentation was visualized by a UV transilluminator (Vilberlourmat, Germany) and the image was captured.

\section{Alkylating reaction in vitro}

An alkylation reaction of the jujube seed extract was performed to understand the interaction of the extract with DNA resulting DNA damage. The alkylation assay was conducted following the method modified by Machana et al. [30]. NBP (final concentration $20 \mathrm{mM}$ ) was prepared in acetonitrile. The buffer solution ( $\mathrm{pH} 4)$ comprised $0.5 \mu \mathrm{M}$ of citric acid, $1 \mu \mathrm{M}$ of boric acid, $4.9 \mu \mathrm{M}$ of sodium chloride, and $1 \mathrm{M}$ sodium hydroxide adjusted to a volume of $10 \mathrm{~mL}$ with deionized water. The mixture of $180 \mu \mathrm{L}$ NBP and $420 \mu \mathrm{L}$ buffer solution was prepared and heated to $70{ }^{\circ} \mathrm{C}$ for $30 \mathrm{~min}$. The extracts at $2 \times \mathrm{IC}_{50}$ concentrations dissolved in acetonitrile were pipetted into the NBP mixture. Then, $120 \mu \mathrm{L}$ of solution mixture was pipetted and added into a $160 \mu \mathrm{L}$ ethanol-acetonitrile mixture at a ratio of $1: 3$. The wavelength of NBP adduct was measured at $580 \mathrm{~nm}$ at different time points $(5,15$, 30, 45, 60 and $75 \mathrm{~min})$.

\section{Phytochemicals screening}

Phytochemical screening was performed to identify the presence of the main phytoconstituents in $0.025 \mathrm{~g}$ of jujube seed extract of each cultivar. Identification of alkaloids, saponins and carbohydrates were tested as per Anandanayaki [35], while identification of flavonoids was conducted as per Bello et al. [36].

\section{Alkaloids identification}

Jujube seed extracts were dissolved in $500 \mu \mathrm{L}$ of methanol and centrifuged (Daihan Scientific, Seoul, Korea) at $268.3 \mathrm{~g}$ for $10 \mathrm{~min}$. $\mathrm{HCl}(1 \%, 1 \mathrm{~mL})$ and 1 drop of Dragendorff's reagent (potassium bismuth iodide) was added to the supernatant. An orange or reddish-brown precipitate indicated a positive test.

\section{Flavonoids identification}

Methanol $(2.5 \mathrm{~mL})$ and $0.5 \mathrm{~mL}$ of $10 \% \mathrm{NaOH}$ were added to the extracts. A few drop of $1 \% \mathrm{HCl}$ was added to $0.5 \mathrm{ml}$ of supernatant. The disappearance of the yellow color indicated the presence of flavonoids.

\section{Saponins identification}

The extracts were diluted with deionized water to a final volume of $1.5 \mathrm{~mL}$ and shaken for $30 \mathrm{~min}$. Permanent foamation indicated the presence of saponins.

\section{Reducing sugar identification}

Fehling's solution A was prepared by dissolving $3.5 \mathrm{~g}$ of copper II sulfate in deionized water and adjusted to $50 \mathrm{~mL}$. Fehling's solution B was prepared by dissolving $17.5 \mathrm{~g}$ potassium sodium tartrate with $5 \mathrm{~g}$ sodium hydroxide in $50 \mathrm{~mL}$ of deionized water. The extracts were diluted in $1.5 \mathrm{~mL}$ of deionized water, heated with Fehling's A and B solution (mixture 1:1) for $10 \mathrm{~min}$. An orange-red precipitate indicated a positive result and the presence of reducing sugar.

\section{Statistical analysis}

The results from multiple independent experiments were expressed as mean \pm standard deviation. Oneway ANOVA was used to test for significant differences between means. $P<0.05$ was considered statistically significant. The variation between groups was tested by the Tukey range test with IBM SPSS software version 19.0 (SPSS Inc., USA). The concentration- and time-dependence shown in the graphs was visually determined.

\section{Results and discussion \\ Characteristics of seeds}

The eight jujube cultivars had diverse seed characteristics (Fig. 1). Generally, the cultivars had different shapes, sizes, and gnarled seed surfaces, with the average width and length being $0.5 \mathrm{~cm}$ and $1.6 \mathrm{~cm}$, respectively. The 'Nomsod' and 'Taiwan' cultivars had the largest seed sizes, while the 'Kaew' cultivar had the smallest.

\section{Antiproliferative effects}

The antiproliferative effects of seed extracts from the eight jujube cultivars were evaluated on the leukemic Jurkat cell line, in comparison with the non-cancer Vero cell line, by neutral red assays (Table 1 ). The cationic neutral red dye can penetrate through cell membranes and lysosomal membranes to attach to anionic charges in the lysosomal matrix of living cells [37].

The antiproliferative effects were represented as $\mathrm{IC}_{50}$ values calculated from linear plots between the concentrations and the \%cell viability. Extracts with the maximum concentration $(500 \mu \mathrm{g} / \mathrm{mL})$ that inhibited cell viability by $<50 \%$ were classified as inactive extracts [30]. Seeds extracted using water, dichloromethane, ethyl acetate, or hexane inhibited Jurkat cell viability by $<50 \%$ 


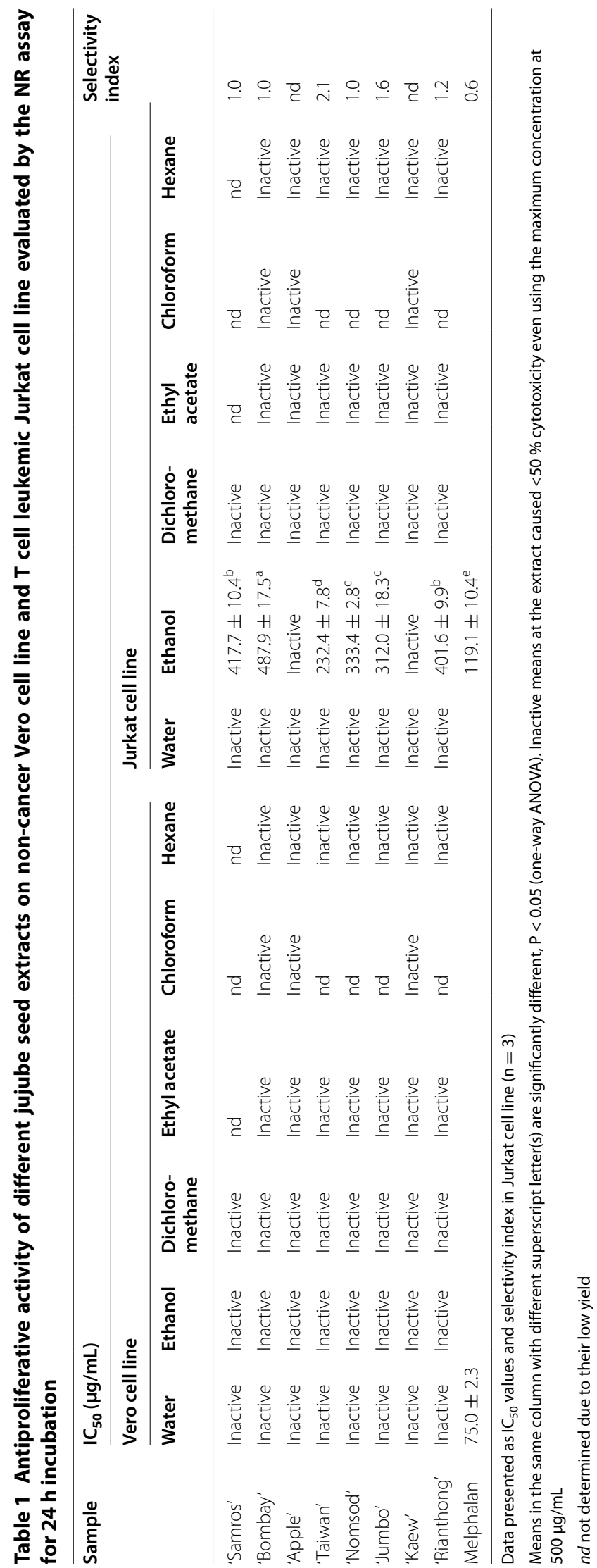


even when the maximum concentration of $500 \mu \mathrm{g} / \mathrm{mL}$ was used. Therefore, these solvent extracts were defined as inactive against both Jurkat and Vero cell lines. The ethanolic extract of 'Taiwan' $(232.4 \pm 7.8 \mu \mathrm{g} / \mathrm{mL})$ exhibited the highest antiproliferative effect, followed by the ethanolic extracts of 'Jumbo' ( $312.2 \pm 18.3 \mu \mathrm{g} / \mathrm{mL})$, 'Nomsod' (333.4 $\pm 2.8 \mu \mathrm{g} / \mathrm{mL})$, 'Rianthong' (401.6 $\pm 9.9 \mu \mathrm{g} /$ $\mathrm{mL}$ ), 'Samros' (417.7 $\pm 10.4 \mu \mathrm{g} / \mathrm{mL}$ ), and 'Bombay' $(487.9 \pm 17.5 \mu \mathrm{g} / \mathrm{mL})$. These six ethanolic extracts showed significant antiproliferative effects compared with the untreated cells (all $P<0.001$ ). The antiproliferative effects of individual pairs of 'Jumbo' vs. Nomsod' $(P=0.322)$ and 'Samros' vs. Rianthong' $(P=0.841)$ did not differ significantly. The chemotherapeutic drug melphalan, used as the positive control, showed nonselective antiproliferative effects on Jurkat cells over Vero cells with $\mathrm{IC}_{50}$ values of $119.1 \pm 10.4 \mu \mathrm{g} / \mathrm{mL}$ vs. $75.0 \pm 2.3 \mu \mathrm{g} /$ $\mathrm{mL}$, respectively. Although the $\mathrm{IC}_{50}$ values of the ethanolic extracts were higher than those of melphalan (i.e., lesser antiproliferative effects) (all $P<0.001)$, the selectivity index of the ethanolic extracts toward Jurkat cells was higher than that of melphalan.

The antiproliferative effects of the ethanolic extracts of the jujube seeds on normal cells were in agreement with previous studies [23, 24, 38]. Ethanolic extracts of $Z$. mauritiana seeds showed antiproliferative effects on HL-60, HeLa, and Molt-4 cell lines without affecting the normal HGF cell line [24], and exerted no cytotoxicity on normal rat liver cells [38]. A chloroform extract of $Z$. jujuba fruit pulp showed antiproliferative effects on MCF-7 and SKBR3 cells without toxicity on normal cells [23]. The present study documented the nonselective cytotoxicity of chloroform seed extracts on Jurkat cells. Owing to the low yields of some chloroform extracts, their cytotoxicity was not determined. Six of the eight ethanolic extracts (i.e., 'Samros,' 'Bombay', 'Taiwan,' 'Nomsod,' 'Jumbo', and 'Rianthong') were selected to determine the mode of cell death.

\section{Apoptosis morphological changes}

As shown in Fig. 2a, the normal nuclei of untreated cells had an intact round morphology, whereas the apoptotic nuclei of cells treated with $500 \mu \mathrm{g} / \mathrm{mL}$ melphalan showed chromatin condensation with heterogeneous staining (Fig. 2b, c) and apoptotic body formation (Fig. 2d). The nuclear morphologies of Jurkat cells treated with the ethanolic seed extracts $(500 \mu \mathrm{g} / \mathrm{mL})$ for $24 \mathrm{~h}$ were shown in Fig. 2e. The six ethanolic jujube seed extracts induced apoptosis with nuclear morphological changes reminiscent of apoptotic characteristics (i.e., cell shrinkage, chromatin condensation, membrane blebbing, and apoptotic body formation).

\section{Mode of cell death}

The stages of apoptosis can be differentiated from necrotic cell death by flow cytometry using Annexin V-FITC/propidium iodide (PI) staining of cells. Apoptotic lymphocytes are identified by their externalized phosphatidylserine (PS) bound with Annexin V-FITC (green), while necrotic cells are identified by their DNA intercalation of PI (red) [39]. During the early stages of apoptosis, the PS comprising the cell membrane flip to the outside and bind with Annexin V-FITC, showing a cell dot plot in quadrant 4. Damaged or injured cells lose their membrane integrity, including nuclear membrane integrity, such that PI can pass through the nuclear membrane and appear in quadrant 1 (necrotic cells). In the late stages of apoptosis, cells are double-stained and appear in quadrant 2 . Normal cells are not stained and appear in quadrant 3.

The ethanolic jujube seed extracts induced cell death in a concentration- and time-dependent manner through diverse modes of cell death (Fig. 3). In general, the extracts induced relatively high late-stage apoptosis and low necrosis compared with melphalan, which induced more early-stage apoptosis. After incubation for $12 \mathrm{~h}$, the $2 \times \mathrm{IC}_{50}$ concentrations of 'Bombay' $(99.2 \pm 0.4 \%)$, 'Samros' (95.1 $\pm 1.8 \%$ ), and 'Nomsod' (90.2 $\pm 2.7 \%$ ) were the first three extracts to induce high total apoptosis $(>90 \%)$ in Jurkat cells. The total apoptosis inductions for 'Bombay' vs. 'Samros' $(P=0.988)$, 'Bombay' vs. Nomsod' $(P=0.928)$, and 'Samros' vs. Nomsod' $(P=0.050)$ did not differ significantly. Under the same conditions $\left(12 \mathrm{~h}, 2 \times \mathrm{IC}_{50}\right)$, only 'Samros' $(29.9 \pm 2.6 \%)(P=0.004)$ and 'Bombay' $(20.9 \pm 1.4 \%)(P<0.001)$ significantly induced higher \%early-stage apoptosis than melphalan $(10.7 \pm 0.4 \%)$. By contrast, the $2 \times \mathrm{IC}_{50}$ concentrations of 'Nomsod' $(79.2 \pm 3.0 \%)(P<0.001)$, 'Bombay' $(78.3 \pm 1.6 \%)(P<0.001)$, and 'Samros' $(65.2 \pm 1.2 \%)$ $(P<0.001)$ caused more significant late-stage apoptosis than melphalan $(3.5 \pm 0.3 \%)$ and the other extracts.

At $24 \mathrm{~h}$, the $2 \times \mathrm{IC}_{50}$ concentration of 'Bombay' showed the highest \%total apoptosis $(97.3 \pm 2.9 \%)$ followed by those of 'Jumbo' (93.7 $\pm 2.4 \%)$, 'Nomsod' (86.0 $\pm 1.9 \%$ ), 'Samros' (80.1 $\pm 3.2 \%)$, 'Rianthong' (53.9 $\pm 2.6 \%)$, melphalan (51.6 $\pm 1.1 \%)$, and 'Taiwan' ( $45.8 \pm 3.0 \%)$. Only the $2 \times \mathrm{IC}_{50}$ concentration of 'Bombay' $(46.1 \pm 2.5 \%)$ $(P<0.001)$ was found to induce early-stage apoptosis significantly more than melphalan $(35.0 \pm 2.2 \%)$. Furthermore, the first three jujube seed extracts that induced high \%late-stage apoptosis were 'Jumbo' ( $80.8 \pm 0.8 \%)$, 'Nomsod' (75.8 $\pm 2.3 \%$ ), and 'Bombay' (51.2 \pm 3.7 ). The \%late-stage apoptosis for 'Jumbo' vs. Nomsod' did not differ significantly $(P=0.599$, one-way ANOVA), while the \%late-stage apoptosis of 'Jumbo' and 'Nomsod' 


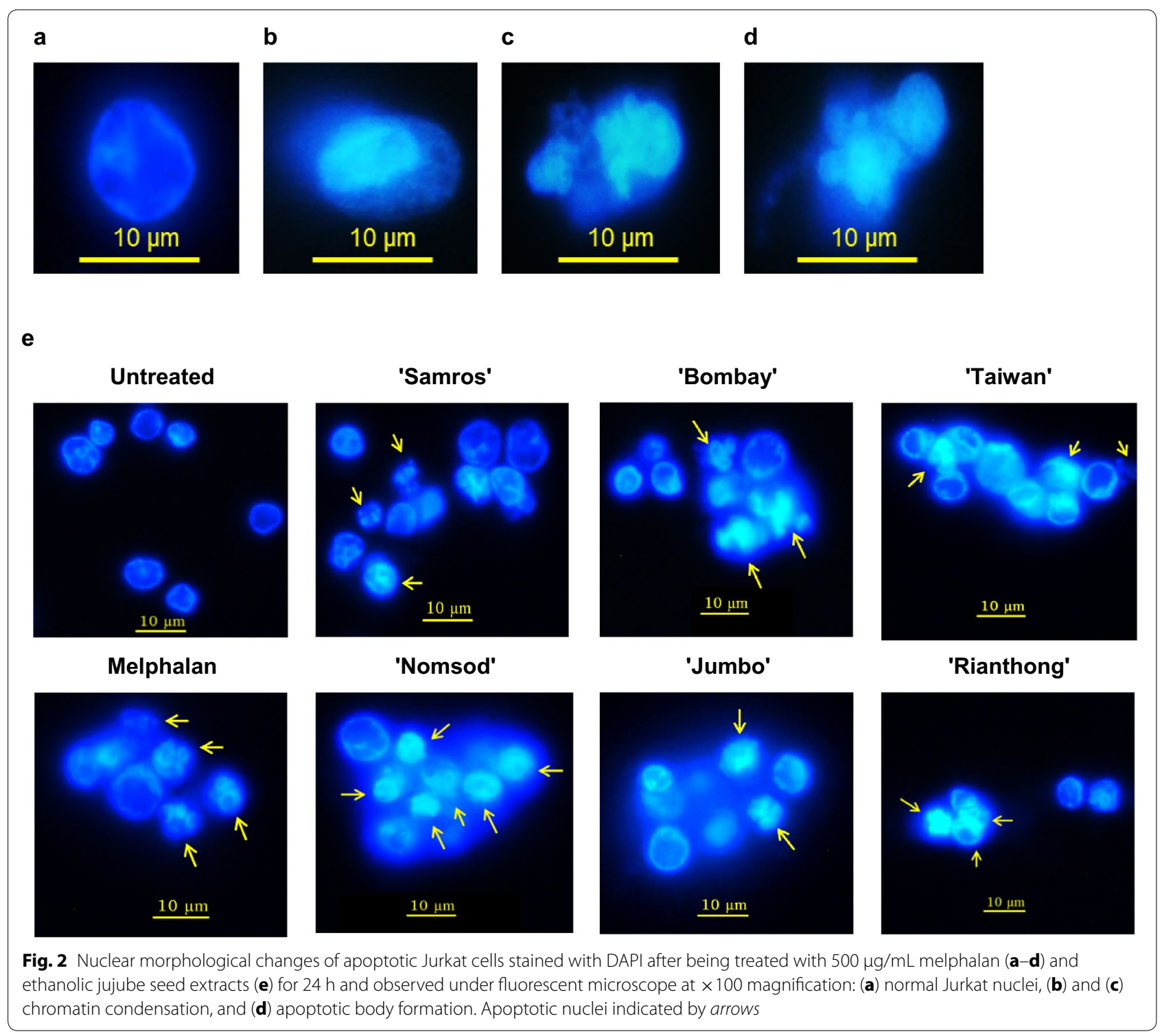

vs. 'Bombay' did differ significantly $(P<0.001$ and $P<0.0 .001$, one-way ANOVA).

The six ethanolic seed extracts induced apoptosis in a concentration-dependent manner. The ranks of the \%total apoptosis-inducing effects at the $2 \times \mathrm{IC}_{50}$ concentrations after $24 \mathrm{~h}$ of incubation were in the descending order: 'Bombay,' 'Jumbo,' 'Nomsod,' 'Samros', 'Rianthong, melphalan, and 'Taiwan'. Apoptosis in the HL-60 cell line was induced by the ethanolic jujube seed extracts in a concentration-dependent manner, and our findings were in agreement with a previous report [24].

The extracts needed to cause less necrotic cell death to achieve effectiveness of their anticancer action. After incubation for $12 \mathrm{~h}$, the $2 \times \mathrm{IC}_{50}$ concentrations of 'Jumbo' (13.0 $\pm 1.5 \%)$, 'Taiwan' (12.6 $\pm 4.9 \%)$, and
'Nomsod' (6.8 $\pm 2.4 \%)$ induced relatively high necrotic cell death compared with the other extracts and melphalan $(0.5 \pm 0.3 \%)$. At $24 \mathrm{~h}$, the $2 \times \mathrm{IC}_{50}$ concentrations of the extracts increased necrotic cell death in the descending order: 'Taiwan' (19.8 $\pm 2.0 \%)$, 'Nomsod' (7.6 $\pm 0.8 \%)$, 'Samros' ( $4.2 \pm 0.5 \%)$, and 'Jumbo' $(2.3 \pm 0.8 \%)$.

\section{Caspase activity}

Apoptosis can be triggered through both extrinsic and intrinsic pathways, involving caspase cascades that act through initiator caspases and executioner caspases [40, 41]. The initiators are caspase- 8 for the extrinsic pathway and caspase-9 for the intrinsic pathway. When the initiator caspases are activated by apoptotic stimuli, the 


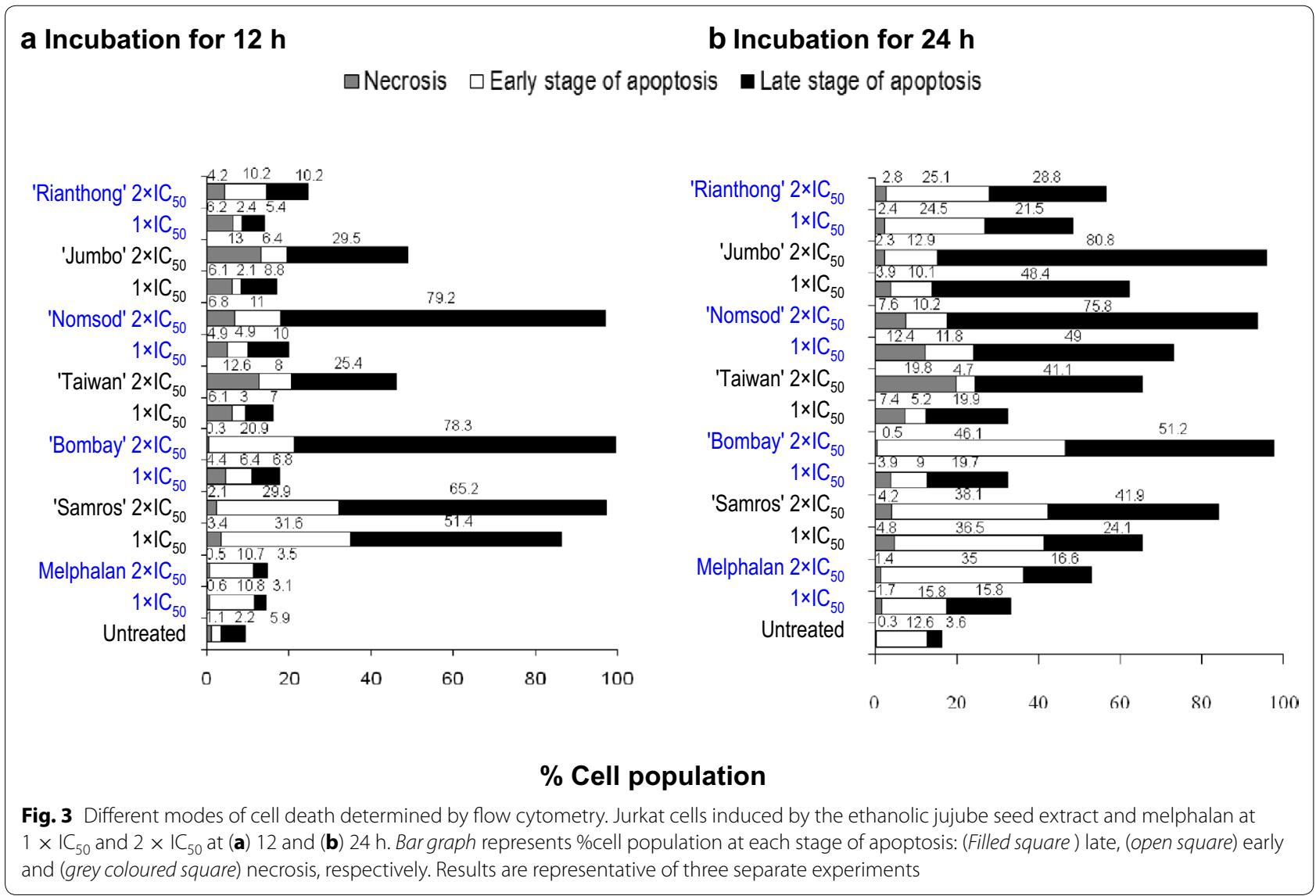

function of the executioner caspase-3 is triggered, which culminates in DNA fragmentation and apoptotic body formation [2, 39, 41]. The present study assessed the activity of both initiator caspases, caspase- 8 and caspase-9, to distinguish the extrinsic pathway from the intrinsic apoptotic pathway. Executioner caspase-3 activity was also determined.

Increased caspase- 3 activity was detected at $30 \mathrm{~min}$ in Jurkat cells (Fig. 4), suggesting that apoptosis induction by the jujube seed extracts was mediated through the caspase-mediated pathways. 'Taiwan,' 'Nomsod,' 'Jumbo', 'Rianthong', and melphalan all significantly increased caspase- 8 and caspase- 9 activity compared with untreated cells at different time points (all $P<0.001$ ). The increases in caspase- 8 activity for 'Taiwan' vs. melphalan differed significantly $(P=0.006)$. However, there were no significant differences in the increases in caspase-8 activity for 'Rianthong' vs. melphalan $(P=0.344)$, 'Jumbo' vs. melphalan $(P=0.402)$, 'Taiwan' vs. 'Rianthong' $(P=0.064)$, 'Taiwan' vs. 'Jumbo' $(P=0.053)$, and 'Rianthong' vs. 'Jumbo' $(P=0.999)$. The increases in caspase-9 activity for 'Nomsod' vs. 'Taiwan' $(P=0.018)$, 'Nomsod' vs. melphalan $(P=0.009)$, 'Taiwan' vs. 'Jumbo' $(P=0.019)$, 'Taiwan' vs.
'Rianthong' $(P=0.003)$, 'Taiwan' vs. melphalan $(P<0.001)$, and 'Jumbo' vs. melphalan $(P=0.009)$ all differed significantly. In contrast, the increases in caspase- 9 activity for 'Nomsod' vs. 'Taiwan' $(P=0.018)$, 'Nomsod' vs. 'Jumbo' $(P=1.000)$, 'Nomsod' vs. Rianthong' $(P=0.773)$, 'Nomsod' vs. melphalan $(P=0.009)$, and 'Jumbo' vs. 'Rianthong' $(P=0.771)$ did not differ significantly.

'Samros' and 'Bombay' did not increase the caspase-8 and -9 activities, although they did activate caspase-3 activity. While activation of caspase- 9 was not evident, the 'Samros' and 'Bombay' extracts were postulated to cleave the caspase- 8 substrate earlier than $15 \mathrm{~min}$ because of the high activity at $15 \mathrm{~min}$ and lower activities at later time points. Activation of caspase- 9 and -3 in a concentration-dependent manner in melanoma cells was previously reported for polysaccharides extracted from the fruit part of $Z$. jujuba [42]. The ethanolic extracts of 'Taiwan', 'Jumbo,' 'Nomsod,' 'Rianthong,' 'Samros', and 'Bombay' induced apoptosis via a caspase-mediated pathway in a similar manner to melphalan, but to different extents. The ethanolic extracts of 'Taiwan', 'Nomsod', 'Jumbo', and 'Rianthong' and melphalan evidently induced apoptosis via the intrinsic and extrinsic pathways. 


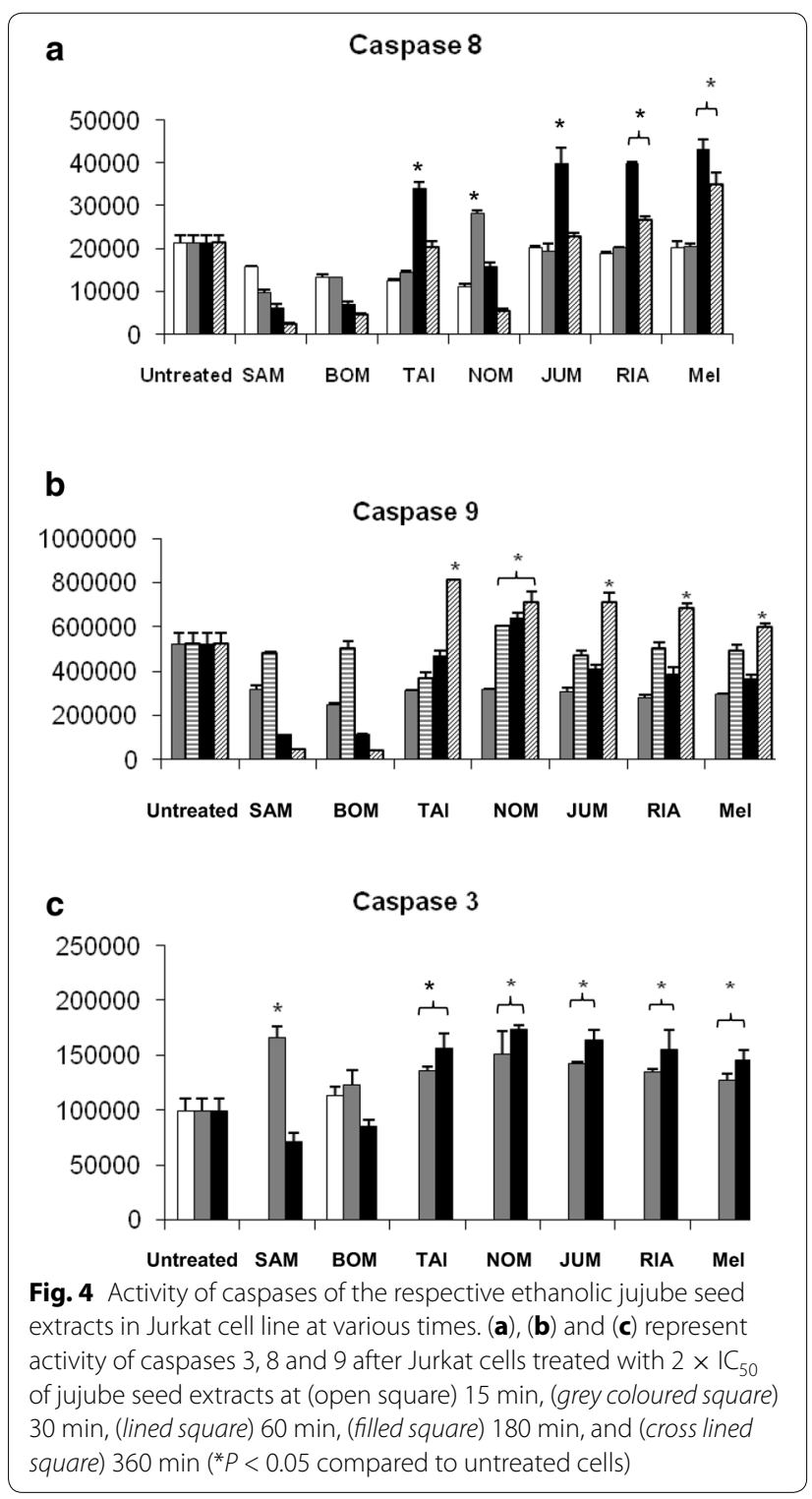

\section{DNA fragmentation}

DNA fragmentation occurs through the activation of endogenous endonucleases with subsequent cleavage of chromatin DNA into internucleosomal fragments of $180 \mathrm{bp}$ and multiples thereof. Similar to the case for melphalan, all six ethanolic jujube seed extracts at $2 \times \mathrm{IC}_{50}$ concentrations clearly exhibited the characteristic DNA ladder formation (Fig. 5).

\section{Alkylation effects of the selected crude extracts compared with melphalan}

An alkylation reaction of the jujube seed extracts was performed to understand the interactions of the extracts with DNA resulting in DNA damage, by testing their alkylating activity. The nitrobenzylpyridine (NBP) assay was used as a model for nucleophilic DNA bases [4345]. This reaction depends on high temperature and low acidic media to catalyze NBP, which is converted into a blue/violet chromophore product. This specific reaction is positively detected in the presence of electrophilic functional groups or alkylating agents. Only the alkylating drug melphalan led to NBP product formation, suggesting that the DNA damage induced by the jujube seed extracts did not arise from an alkylation reaction. The findings also implied that no electrophilic functional groups were present in the constituents of the jujube seed extracts.

\section{Phytochemical constituents of the extracts}

The phytochemical identification of the ethanolic jujube seed extracts showed that alkaloids predominated in all jujube cultivated species followed by reducing sugars (Table 2). Neither saponins nor flavonoids were found in the cultivars tested. The 'Apple,' 'Taiwan', and 'Nomsod' extracts had relatively high amounts of alkaloids, followed by the 'Samros', 'Bombay', 'Jumbo', 'Kaew', and 'Rianthong' extracts. The 'Nomsod' and 'Rianthong' extracts had relatively high amounts of reducing sugars.

Ethanolic extracts of $Z$. mauritiana seeds contained alkaloids, terpenes, flavonoids, saponins, and tannins [46]. The alkaloids exhibited anticancer activity [47]. Alkaloids from $Z$. jujuba seeds (i.e., sanjoine K, zizyphusine, and amphibine) processed a sedative action [48, 49]. The fruit pulp of $Z$. jujuba induced apoptosis in various cancer cells, including breast cancer, liver cancer, and leukemia cells $[7,23]$. The bioactive compounds in jujube with the anticancer effects (through induction of apoptotic cell death) were triterpene and betulinic acid [23, $24,46,50,51]$.

The ethanolic extracts of jujube seeds from different cultivars exhibited diverse inhibition of leukemic Jurkat cell viability. The chloroform extracts and melphalan were toxic toward both Jurkat and Vero cells. The ethanolic extracts selectively caused death in Jurkat cells, but not in normal Vero cells. The 'Taiwan' extract exhibited the highest cytotoxicity followed by the 'Jumbo', 'Nomsod, 'Rianthong,' 'Samros', and 'Bombay' extracts. The modes of cell death induced by these six jujube extracts were distinguished and confirmed by different methods. The Jurkat cells treated with these six ethanolic extracts exhibited various stages of apoptotic nuclear morphological alterations similar to those found in Jurkat cells treated with melphalan. The analyses for mode of cell death at $12 \mathrm{~h}$, detected by flow cytometry, revealed that the 'Bombay' extract at $2 \times \mathrm{IC}_{50}$ induced significantly more apoptosis than the other extracts and melphalan (99.2 $\pm 0.4 \% ; P<0.001)$. At $24 \mathrm{~h}$, the 'Bombay', 'Jumbo', and 'Nomsod' extracts induced apoptotic cell death at 


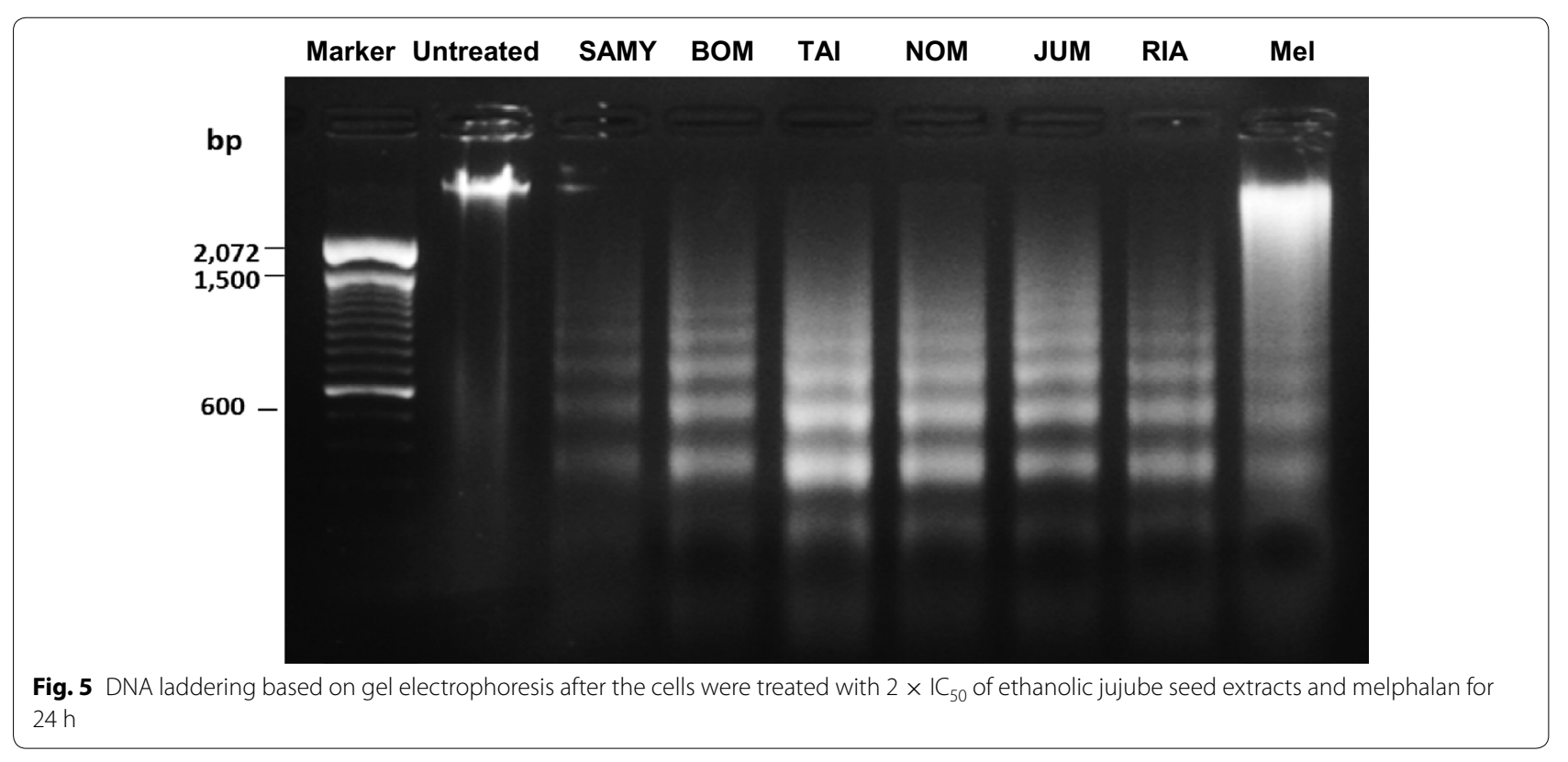

Table 2 Phytochemicals screening of the ethanolic seed extracts of eight jujube cultivars

\begin{tabular}{|c|c|c|c|c|c|c|c|c|c|}
\hline \multirow[t]{2}{*}{ Phyto-chemicals } & \multirow[t]{2}{*}{ Presence of phyto-chemical } & \multicolumn{8}{|c|}{ Jujube cultivars } \\
\hline & & 'Samros' & 'Bombay' & 'Apple' & 'Taiwan' & ‘Nomsod' & 'Jumbo' & 'Kaew' & 'Rianthong' \\
\hline Alkaloids & Orange or reddish brown precipitate & ++ & ++ & +++ & +++ & +++ & ++ & ++ & + \\
\hline Flavonoids & Colorless & - & - & - & - & - & - & - & - \\
\hline Saponins & Permanent foam & - & - & - & - & - & - & - & - \\
\hline Reducing sugar & Orange red precipitate & - & - & - & - & +++ & - & ++ & +++ \\
\hline
\end{tabular}

- , absence of phytochemicals; + , presence of phytochemicals; +++ , indicates the highest level; + , indicates the lowest level of phytochemical in positive results

$97.3 \pm 2.9 \%, 93.7 \pm 2.4 \%$, and $86.0 \pm 1.9 \%$, respectively. Although 'Taiwan' and 'Jumbo' were the first two cultivars possessing high cytotoxicity, they also caused higher degrees of undesirable necrotic cell death. DNA damage was detected in the Jurkat cells treated with the 'Taiwan', 'Jumbo', 'Nomsod, 'Rianthong', 'Samros', and 'Bombay' extracts. This DNA damage did not occur via an alkylation reaction between the extracts and the nucleophilic DNA model, as confirmed by the NBP assays. The Jurkat cellular changes, reflecting apoptosis induced by the seed extracts of the six jujube cultivars, were mediated by caspases. Increased caspase- 3 activity was detected after all six extract treatments. The 'Taiwan', 'Nomsod,' 'Jumbo', and 'Rianthong' extracts induced apoptosis through both extrinsic and intrinsic apoptosis pathways, based on increases in caspase- 8 and -9 activities, respectively. The 'Samros' and 'Bombay' extracts seemed to augment the initiator caspase- 8 activity at an earlier time point, but did not induce the intrinsic apoptosis pathway.

\section{Conclusions}

The six active extracts ('Taiwan,' 'Jumbo', 'Nomsod', 'Rianthong,' 'Samros' and 'Bombay') contained alkaloids and reducing sugars, and induced caspase-dependent apoptosis in human Jurkat leukemia T cells.

\section{Abbreviations}

APP: 'Apple' cultivar; BOM: 'Bombay' cultivar; JUM: 'Jumbo' cultivar; KAE: 'Kaew' cultivar; Mel: chemotherapeutic drug melphalan; NOM: 'Nomsod'cultivar; RIA: 'Rianthong' cultivar; SAM: 'Samros' cultivar; TAl:' 'Taiwan' cultivar.

\section{Authors' contributions}

NW designed the study. NT performed the experiment, collected, and analyzed the data. NW and NT wrote the manuscript. NW, SB and SS revised the manuscript. All authors read and approved the final manuscript.

\section{Author details}

${ }^{1}$ Graduate School, Faculty of Pharmaceutical Sciences, Khon Kaen University, Khon Kaen 40002, Thailand. ${ }^{2}$ Faculty of Pharmaceutical Sciences, Khon Kaen University, Khon Kaen 40002, Thailand. ${ }^{3}$ Faculty of Associate Medical Sciences, Khon Kaen University, Khon Kaen 40002, Thailand. ${ }^{4}$ Department of Food Technology and Nutrition, Mahasarakham University, Mahasarakham 44000, Thailand. 


\section{Acknowledgements}

NT was grateful to the Faculty of Pharmaceutical Sciences for the Master degree scholarship in the second semester of 2013. The Thai Research Fund (RDG5420072) financially supported this research. The authors thank Mr. Bryan Roderick Hamman and Mrs. Janice Loewen-Hamman for assistance with the English-language presentation.

\section{Competing interests}

The authors declare that they have no competing interests.

Received: 7 December 2014 Accepted: 23 March 2016 Published online: 01 April 2016

\section{References}

1. Khazir J, Mir BA, Pilcher L, Riley DL. Role of plants in anticancer drug discovery. Phytochemistry Lett. 2014;7:173-81.

2. Brunelle JK, Zhang B. Apoptosis assays for quantifying the bioactivity of anticancer drug products. Drug Resist Updat. 2010;13:172-9.

3. Yan YH, Gao ZP. Industrialization of Chinese jujube. J Northwest Sci Tech Univ Agri For. 2002;30:95-8.

4. Williams JT. From introduction, taxonomy, and history. In: Smith RW, Haq N, Dunsiger Z, editors. Fruits for the future 2 (revised edition): ber and other jujubes. Southampton: Int Cen Underutil Crops; 2006. p. 1-17.

5. Li JW, Fan LP, Ding SD, Ding XL. Nutritional composition of five cultivars of Chinese jujube. Food Chem. 2007;103:454-60.

6. Saha D, Srivastava SC, Ramani R. Genetic relationships among fruit cultivars and host plants of Indian lac insect in ber (Ziziphus mauritiana Lam.) revealed by RAPD and ISSR markers. Indian. J Biotechnol. 2012;12:170-7.

7. Huang X, Kojima-Yuasa A, Norikura T, Kennedy DO, Hasuma T, MatsuiYuasa I. Mechanism of the anti-cancer activity of Zizyphus jujuba in HepG2 cells. Am J Chin Med. 2007;35:517-32.

8. Kumar S, Jawaid T, Dubey SD. Therapeutic plants of Ayurveda; a review on anticancer. Pharm J. 2011;3:1-11.

9. Eley JG, Dovlatabadi H. Permeability enhancement activity from Ziziphus jujuba. Pharm Biol. 2002;40:149-53.

10. Peng WH, Hsieh MT, Lee YS, Lin YC, Liao J. Anxiolytic effect of seed of Ziziphus jujuba in mouse models of anxiety. J Ethnopharmacol. 2000;72:435-41.

11. Su BN, Cuendet M, Farnsworth NR, Fong HH, Pezzuto JM, Kinghorn AD Activity-guided fractionation of the seeds of Ziziphus jujuba using a cyclooxygenase-2 inhibitory assay. Planta Med. 2002;68:1125-8.

12. Heo HJ, Park YJ, Suh YM, Choi SJ, Kim MJ, Cho HY, Shin DH. Effects of oleamide on choline acetyltransferase and cognitive activities. Biosci Biotechnol Biochem. 2003:67:1284-91.

13. Lamien-Meda A, Lamien CE, Compaoré MMY, Meda RNT, Kiendrebeogo M, Zeba B, Nacoulma OG. Polyphenol content and antioxidant activity of fourteen wild edible fruits from Burkina Faso. Molecules. 2008;13:581-94.

14. Memarpoor-Yazdi M, Mahaki H, Zare-Zardini H. Antioxidant activity of protein hydrolysates and purified peptides from Zizyphus jujuba fruits. J Funct Foods. 2013;5:62-70.

15. Su XS, Chen ZD, Jiao BL, Huang QM, Li WY. Studies on anti-allergic activity of common foodstuffs in China and their constituents. J Southwest Agri Univ. 2000;21:77-80

16. Suttisri R, Lee IS, Kinghorn AD. Plant-derived triterpenoid sweetness inhibitors. J Ethnopharmacol. 1995:47:9-26.

17. Dahiru D, Obidoa O. Pretreatment of albino rats with aqueous leaf extract of Ziziphus mauritiana protects against alcohol-induced liver damage. Trop J Pharm Res. 2007;6:705-10

18. Siddharth P, Kailash P, Niraj V, Karuna M, Vimal P, Bharadia P, Pundarikakshudu K. Antiulcer activity of methanolic extract of Ziziphus mauritiana Stem Bark. Int J Pharm Phytochem Res. 2010;2:6-11.

19. Gupta M, Mazumder UK, Vamsi MLM, Sivakumar T, Kandar CC. Antisteroidogenic activity of the two Indian medicinal plants in mice. J Ethnopharmacol. 2004;90:21-5.

20. Adamu HM, Abayeh OJ, Ibok NU, Kafu SE. Antifungal activity of extracts of some Cassia, Detarium and Ziziphus species against dermatophytes. Nat Prod Radiance. 2006;5:357-60.
21. Dahiru D, Sini JM, John-Africa L. Antidiarrhoeal activity of Ziziphus mauritiana root extract in rodents. Afr J Biotechnol. 2006;5:941-5.

22. Mahajan R, Chopda M. Phyto-Pharmacology of Ziziphus jujuba Mill-A plant review. Pharmacogn Rev. 2009;3:320-9.

23. Plastina P, Bonofiglio D, Vizza D, Fazio A, Rovito D, Giordano C, Gabriele B. Identification of bioactive constituents of Ziziphus jujube fruit extracts exerting antiproliferative and apoptotic effects in human breast cancer cells. J Ethnopharmacol. 2012;140:325-32.

24. Mishra T, Khullar M, Bhatia A. Anticancer potential of aqueous ethanol seed extract of Ziziphus mauritiana against cancer cell lines and Ehrlich ascites carcinoma. Evid Based Complement Alternat Med. 2011;2011:1-11.

25. Buanong M, Techavuttiporn C, Boonyaritthongchai P, Lichanporn I. Analysis of bioactive compound contents in commercial fruits locally cultivated in Thailand. 2009. http://elibrary.trf.or.th/fullP/RDG5220054// RDG5220054_abstract.pdf.

26. Taechakulwanijya N, Weerapreeyakul N, Barusrux S, Siriamornpun S. Apoptosis induction effect of three jujube cultivars in HepG2 and Jurkat cell lines. Int J Biosci Biochem Bioinforma (IJBBB). 2013;3:540-4.

27. Siriamornpun S, Weerapreeyakul N, Barusrux S. Bioactive compounds and health implications are better for green jujube fruit than for ripe fruit. J Funct Foods. 2015;12:246-55.

28. Grebenstein C, Choi YH, Rong J, De Jong TJ, Tamis WLM. Metabolic fingerprinting reveals differences between shoots of wild and cultivated carrot (Daucus carota L.) and suggests maternal inheritance or wild trait dominance in hybrids. Phytochemistry. 2011;72:1341-7.

29. Cherif AO, Messaouda MB, Kaabi B, Pellerin I, Boukhchina S, Kallel H, Pepe C. Characteristics and pathways of bioactive 4-desmethylsterols, triterpene alcohols and 4a-monomethylsterols, from developing Tunisian cultivars and wild peanut (Arachis hypogaea L.). Plant Physiol Bioch. 2011;49:774-81.

30. Machana S, Weerapreeyakul N, Barusrux S, Nonpunya A, Sripanidkulchai B, Thitimetharoch T. Cytotoxic and apoptotic effects of six herbal plants against the human hepatocarcinoma (HepG2) cell line. Chinese Med. 2011;6:39.

31. Bézivin C, Tomasi S, Lohézic-Le Dévéhat F, Boustie J. Cytotoxic activity of some lichen extracts on murine and human cancer cell lines. Phytomedicine. 2003;10:499-503.

32. De Castro LFP, Zacharias M. DAPI binding to the DNA minor groove: a continuum solvent analysis. J Mol Recognit. 2002;15:209-20.

33. Nasri T, Bosch RR, Voorde S, Fink-Gremmels J. Differential induction of apoptosis by type A and B trichothecenes in Jurkat T-lymphocytes. Toxicol In Vitro. 2006;20:832-40.

34. Hickey TE, Majam G, Guerry P. Intracellular survival of Campylobacter jejuni in human monocytic cells and induction of apoptotic death by cytholethaldistending toxin. Infect Immun. 2005;73:5194-7.

35. Anandanayaki S. Comparative pharmacognostical studies on selected plants (Pedalium murex Roen ex. L. and Martynia annua L.). Ph.D. thesis. Tamil University, Department of Environmental and Herbal Science; 2010.

36. Bello IA, Ndukwe GI, Audu OT, Habila JD. A bioactive flavonoid from Pavetta crassipes K. Schum. Org Med Chem Lett. 2011;1:14.

37. Shirazi FH, Ahmadi N, Kamalinejad M. Evaluation of northern Iran Mentha pulegium L. cytotoxicity. DARU. 2004;12:106-10.

38. Suriyavadhana M, Pakutharivu T. Evaluation of acute and sub-acute toxicity of ethanol extracts of Entada pursaetha, Toddalia aculeata, and Ziziphus mauritiana. World J Life Sci Med Res. 2011;1:43-7.

39. Dai ZJ, Gao J, Ji ZZ, Wang XJ, Ren HT, Liu XX, Wu WY, Kang HF, Guan HT. Matrine induces apoptosis in gastric carcinoma cells via alteration of Fas/ FasL and activation of caspase-3. J Ethnopharmacol. 2009;123:91-6.

40. Budihardjo I, Oliver H, Lutter M, Luo X, Wang X. Biochemical pathways of caspase activation during apoptosis. Annu Rev Cell Dev Biol. 1999:15:269-90.

41. Mcllwain DR, Berger T, Mak TW. Caspase functions in cell death and disease. Cold Spring Harb Perspect Biol. 2013;5:a008656.

42. Hung CF, Hsu BY, Chang SC, Chen BH. Antiproliferation of melanoma cells by polysaccharide isolated from Zizyphus jujuba. Nutrition. 2012;28:98-105.

43. Meier I, Shephard SE, Lutz WK. Nitrosation of aspartic acid, aspartame, and glycine ethylester. Alkylation of 4-(p-nitrobenzyl) pyridine (NBP) in vitro and binding to DNA in the rat. Mutat Res. 1990;238:193-201. 
44. Dierickx KME, Journé F, Gerbaux P, Morandini R, Kauffmann JM, Ghanem GE. Improving the spectrophotometric determination of the alkylating activity of anticancer agents: a new insight into the mechanism of the NBP method. Talanta. 2009;77:1370-5.

45. Gómez-Bombarelli R, González-Pérez M, Calle E, Casado J. Potential of the NBP method for the study of alkylation mechanisms: NBP as a DNAmodel. Chem Res Toxicol. 2012;25:1176-91.

46. Mishra T, Bhatia A. Augmentation of expression of immunocytes' functions by seed extract of Ziziphus mauritiana (Lamk.). J Ethnopharmacol. 2010;127:341-5.

47. Saxena M, Saxena J, Nema R, Singh D, Gupta A. Phytochemistry of medicinal plants. J Pharmacogn Phytochem. 2013;1:168-82.

48. Liu J, Chen B, Yao S. Simultaneous analysis and identification of main bioactive constituents in extract of Zizyphus jujuba var. sapinosa
(Zizyphispinosi semen) by high performance liquid chromatographyphotodiode array detection-electrospray mass spectrometry. Talanta. 2007;71:668-75

49. Han BH, Park MH, Park JH. Chemical and pharmacological studies on sedative cyclopeptide alkaloids in some Rhamnaceae plants. Pure Appl Chem. 2009;61:443-8.

50. Pisha E, Chai H, Lee IS, Chagwedera TE, Farnsworth NR, Cordell GA, Brown DM. Discovery of betulinic acid as a selective inhibitor of human melanoma that functions by induction of apoptosis. Nat Med. 1995;1:1046-51.

51. Lee SM, Min BS, Lee CG, Kim KS, Kho YH. Cytotoxic triterpenoids from the fruits of Zizyphus jujuba. Planta Med. 2003;69:1051-4.

\section{Submit your next manuscript to BioMed Central and we will help you at every step:}

- We accept pre-submission inquiries

- Our selector tool helps you to find the most relevant journal

- We provide round the clock customer support

- Convenient online submission

- Thorough peer review

- Inclusion in PubMed and all major indexing services

- Maximum visibility for your research

Submit your manuscript at www.biomedcentral.com/submit
(O) Biomed Central 